\title{
Antagonism of Some Aquatic Hyphomycetes against Plant Pathogenic Fungi
}

\author{
S.C. Sati and P. Arya* \\ Department of Botany, Kumaun University, Nainital, India \\ E-mail: arya.pratibha 82@yahoo.co.in
}

Received September 24, 2009; Revised April 3, 2010; Accepted April 12, 2010; Published May 4, 2010

The antagonistic activity of five aquatic hyphomycetes, viz., Heliscus lugdunensis, Tetrachaetum elegans, Tetracladium breve, T. marchalianum, and T. nainitalense, against seven plant pathogenic fungi was studied using a dual culture technique. Inhibitory activity of tested aquatic hyphomycetes was determined by measuring the radial growth of plant pathogenic fungi on dual culture plates. Tetrachaetum elegans showed antagonistic activity against Colletotrichum falcatum, Fusarium oxysporum, Pyricularia oryzae, Sclerotium sclerotiorum, and Tilletia indica. Heliscus lugdunensis showed antagonism against only two plant pathogenic fungi, Rhizoctonia solani and Colletotrichum falcatum. Tetracladium breve, $T$. marchalianum, and $T$. nainitalense showed no response towards tested plant pathogenic fungi.

KEYWORDS: antagonism, aquatic hyphomycetes, root endophytic fungi, Tetrachaetum elegans, Heliscus lugdunensis

\section{INTRODUCTION}

Aquatic hyphomycetes are conidial fungi that are abundant in almost all freshwater bodies throughout the world[1,2,3]. Occurrence of these fungi as root endophytes in healthy plants indicates that they are biologically important and may have a beneficial role in plant health[4,5]. The intra- and interspecific interaction of aquatic hyphomycetes in relation to aquatic ascomycetes and release of diffusible inhibitory substances have been reported by some workers[6,7,8].

Interaction of aquatic hyphomycetes with bacteria and terrestrial fungi has been suggested by Chamier et al.[9] and Gulis and Suberkropp[10]. A new antimicrobial compound "Quinapathin" has been described from the aeroaquatic hyphomycete Helicoon richonis[11,12]. Likewise, isolation and structural determination of the antimicrobial compound "Anguillosporal", from Anguillospora longissima, has resulted in the discovery of a new metabolite[13].

Previously, Platas et al.[14] and Gulis and Stephanovich[15] demonstrated the antagonistic activity of a few aquatic hyphomycetes. According to Gloer[16], the secondary metabolites of aquatic hyphomycetes could result in the discovery of new natural bioactive products of medicinal and agricultural importance. In a study on antibmicrobial effects of aquatic hyphomycetes, Gulis and Stepahnovich[15] suggested that due to their specific habitat, they may have biosynthetic capabilities different from those of terrestrial fungi. 
A number of aquatic hyphomycetes have been isolated as root endophytes of some plants[17,18,19]. Nevertheless, the information on the antagonistic activity of aquatic hyphomycetes is quite meager. The present investigation evaluated the antagonistic activity of Heliscus lugdunensis Sacc. \& Therry, Tetrachaetum elegans Ingold, Tetracladium breve Roldan, T. marchalianum De Wildeman, and $T$. nainitalense Sati \& Arya isolated from the roots of riparian plants against plant pathogenic fungi.

\section{MATERIALS AND METHODS}

Roots of healthy riparian plants (Table 1) were collected from ravine areas near Nainital, Uttarakhand, India $\left(29.39^{\circ} \mathrm{N} 79.45^{\circ} \mathrm{E}\right)$ in the western part of Central Himalaya. Root pieces $(1-2 \mathrm{~cm}$ in size) were washed in running water, then surface sterilized by immersing them in a $0.01 \%$ sodium hypochlorite solution for $5 \mathrm{~min}$ and then in $96 \%$ ethanol for $30 \mathrm{sec}[17]$. The pieces were placed onto 2\% Malt Extract (ME) agar and incubated at $20 \pm 2{ }^{\circ} \mathrm{C}$ for $10-15$ days in the dark. Isolations were made from the hyphal growth emanating from the root pieces. The isolates were identified with the help of relevant monographs and papers (Table 1).

TABLE 1

Fungal Isolates, Their Host, and Location at Nainital, India

\begin{tabular}{lll}
\hline Fungal Isolates & \multicolumn{1}{c}{ Host Plant } & Location \\
\hline Tetrachaetum elegans Ingold & Pilea scripta (Buch.-Ham. Ex D. Don) Wedd. & Vinayak \\
Heliscus lugdunensis Sacc. \& Therry & Strobilanthes alatus Nees & Ratighat \\
Tetracladium marchalianum De Wildeman & Geranium nepalense Sweet & Vinayak \\
T. breve Roldan & Eupatorium adenophorum Sprengel & Gufa Mahadev \\
T. nainitalense Sati \& Arya & E. adenophorum Sprengel & Gufa Mahadev \\
\hline
\end{tabular}

Seven plant pathogenic fungi (test fungi), viz., Colletotrichum falcatum, Fusarium oxysporum, Pyricularia oryzae, Rhizoctonia solani, Sclerotinia sclerotiorum, Sclerotium rolfsii, and Tilletia indica were obtained from G.B. Pant University of Agriculture and Technology, Pantnagar, (USN), India.

\section{Antagonistic Activity (Dual Culture)}

Antagonistic activity of aquatic hyphomycetes against the test fungi was studied using a dual culture technique. Mycelial disks ( $5 \mathrm{~mm}$ diameter) of aquatic hyphomycetes and the test fungi were cut from the periphery of actively growing colonies and aseptically placed $2.5 \mathrm{~cm}$ apart on assay plates $(90 \mathrm{~mm}$ diameter) containing $15 \mathrm{ml}$ of $2 \% \mathrm{ME}$ agar (Figs. 1 and 2). Three replicate plates of each combination of dual cultures were incubated at $20 \pm 2^{\circ} \mathrm{C}$ for 4 days in the dark.

The antagonistic activity of aquatic hyphomycetes was analyzed by measuring the radial growth of the test fungi on day 4 following inoculation. The measurements were taken in two directions: $\mathrm{R}_{1}$ (radius in opposite direction) and $\mathrm{R}_{2}$ (radius in direction of the aquatic hyphomycetes). $\mathrm{R}_{1}$ distance was also considered as negative control. Percent inhibition of radial growth was calculated as suggested by Fokkema[20] and Shearer and Zare-Maivan[8]:

$$
\text { Percent Inhibition }=\frac{R_{1}-R_{2}}{R_{1}} \times 100
$$



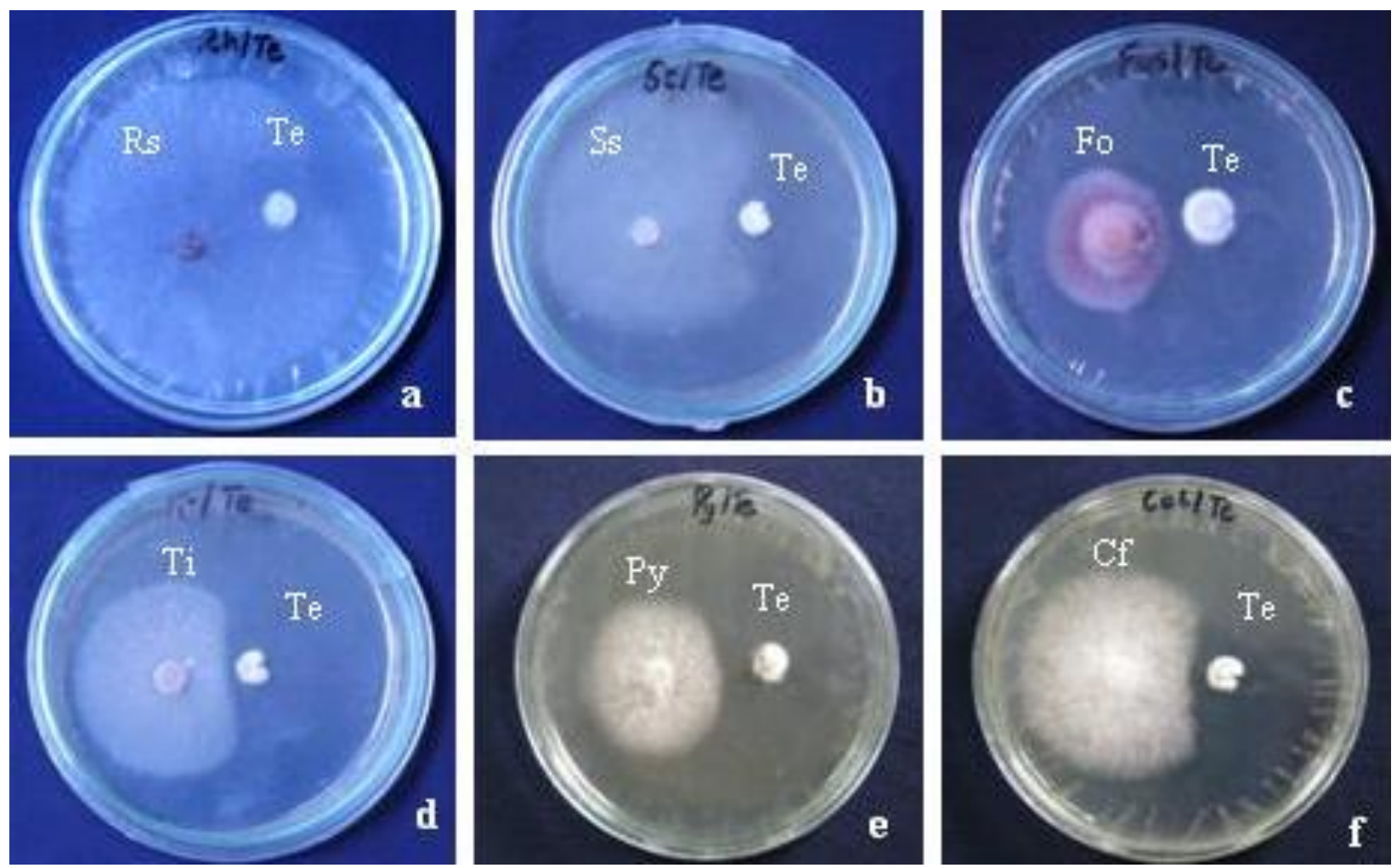

FIGURE 1. Inhibition of plant pathogenic fungi by Tetrachaetum elegans: (a) Rhizoctonia solani, (b) Sclerotinia sclerotiorum, (c) Fusarium oxysporum, (d) Tilletia indica, (e) Pyricularia oryzae, (f) Colletotrichum falcatum.
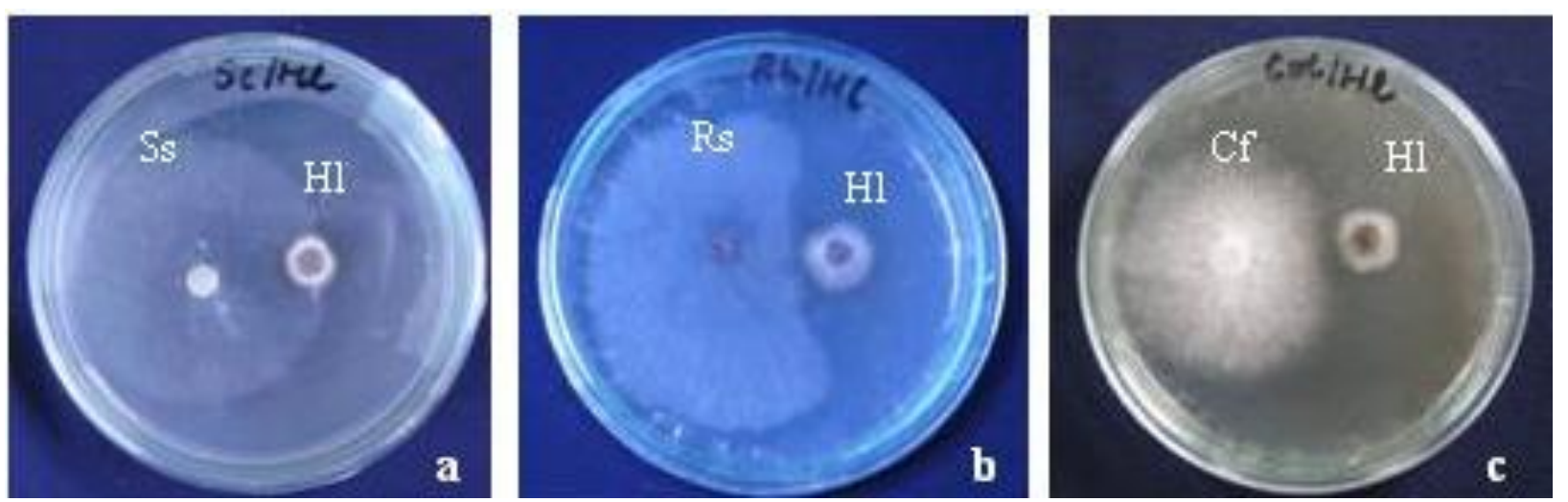

FIGURE 2. Inhibition of plant pathogenic fungi by Heliscus lugdunensis: (a) Sclerotinia sclerotiorum, (b) Rhizoctonia solani, (c) Colletotrichum falcatum.

\section{Analysis of Data}

The differences in radial length were analyzed statistically using paired t-tests. A mean value of percent inhibition followed by standard error of mean (SEM) was also determined. 


\section{RESULTS AND DISCUSSION}

The antagonistic activity of five aquatic hyphomycetes against seven plant pathogenic fungi is presented in Table 2. Tetrachaetum elegans showed a significant percent $(p<0.05)$ of inhibitory activity towards five plant pathogenic fungi, viz., Colletotrichum falcatum, Fusarium oxysporum, Pyricularia oryzae, Sclerotinia sclerotiorum, and Tilletia indica (Fig. 1, b-f). Heliscus lugdunensis showed inhibitory activity, but only towards two plant pathogenic fungi, viz., Rhizoctonia solani and Colletotrichum falcatum (Fig. 2, b-c). Tetracladium marchalianum, T. breve, and T. nainitalense exhibited no inhibitory effect against the tested plant pathogenic fungi (Table 2).

\section{TABLE 2}

Percent Inhibition of Seven Pathogenic Fungi Against Five Aquatic Hyphomycetes ( \pm SEM Based on Three Replicates)

\begin{tabular}{|c|c|c|c|c|c|c|}
\hline & \multirow[b]{2}{*}{ Test Fungi } & \multicolumn{5}{|c|}{ Fungal Isolates } \\
\hline & & $\begin{array}{l}\text { Tetrachaetum } \\
\text { elegans }\end{array}$ & $\begin{array}{c}\text { Heliscus } \\
\text { lugdunensis }\end{array}$ & $\begin{array}{l}\text { Tetracladium } \\
\text { marchalianum }\end{array}$ & T. breve & T. nainitalense \\
\hline \multirow{7}{*}{ 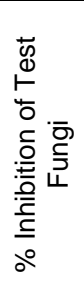 } & Rhizoctonia solani & - & $45.24 \pm 0.03$ & - & - & - \\
\hline & Pyricularia oryzae & $27.05 \pm 0.15$ & - & - & - & - \\
\hline & Sclerotinia sclerotiorum & $25.63 \pm 0.06$ & - & - & - & - \\
\hline & Colletotrichum falcatum & $33.64 \pm 0.10$ & $25.28 \pm 0.06$ & - & - & - \\
\hline & Fusarium oxysporum & $30.89 \pm 0.06$ & - & - & - & - \\
\hline & Sclerotium rolfsii & - & - & - & - & - \\
\hline & Tilletia indica & $30.42 \pm 0.06$ & - & - & - & - \\
\hline
\end{tabular}

$-=$ No activity .

The paired t-test performed on radial growth values of Tetrachaetum elegans were significantly different for Pyricularia oryzae ( $p<0.05)$, Sclerotinia sclerotiorum $(p<0.05)$, Colletotrichum falcatum $(p<0.05)$, Fusarium oxysporum $(p<0.01)$, and Tilletia indica $(p<0.01)$. Heliscus lugdunensis differences were significant for Rhizoctonia solani $(p<0.01)$ and Colletotrichum falcatum $(p<0.01)$.

In the present study, endophytic aquatic hyphomycetes isolated from riparian plant roots were screened for their antifungal activity against seven plant pathogenic fungi. Earlier antagonistic studies using metabolites of ectomycorrhizal fungi and other endophytic fungi showed positive results[15,21,22,23]. However, in this study, the antagonistic activity of aquatic hyphomycetes against plant pathogenic fungi was tested by using a dual culture technique (Figs. 1 and 2). It was interesting to note that $H$. lugdunensis showed a significant antagonistic activity against $R$. solani and $C$. falcatum (Fig. 2), whereas Gulis and Stephanovich[15] observed H. lugdunensis as biologically inactive against Gramnegative and Gram-positive bacteria, yeast, and hyphomycetes when using metabolites in an "agar well" technique. The variation in the present study may be due, perhaps, to the use of different techniques. This may also be supported by the observation of Tian et al.[24] that endophytic fungi showed antagonism in the dual culture test, whereas their metabolites showed no or little activity.

All the previous studies on antifungal activity were determined by using metabolites of endophytic aquatic hyphomycetous fungi, but the present investigation was conducted to check the antagonistic role of these fungi by using dual culture for the first time. The present study clearly indicates that aquatic hyphomycetous fungi synthesize substances that inhibit the growth of certain phytopathogens. However, further screening of the compounds responsible for the antagonistic activity is required. This antagonistic property of aquatic hyphomycetes may also be used in the future for the exploitation of naturally occurring compounds, which can compete with synthetic fungicides. 


\section{ACKNOWLEDGMENTS}

This study was supported by a grant from the Department of Science and Technology (DST), Government of India. The authors would like to thank the Head of the Department of Botany, Kumaun University, Nainital, India for providing the lab facility and Dr. Kapil Khulbe for his help in preparing the experiment. The paper benefited from the suggestions of three anonymous reviewers and the editors.

\section{REFERENCES}

1. Webster, J. and Descals, E. (1981) Morphology, distribution and ecology of conidial fungi in freshwater habitats. In The Biology of Conidial Fungi. Cole, G.T. and Kendrick, B., Eds. Academic Press, New York. pp. 295-355.

2. Marvanova, L. and Barlocher, F. (1988) Hyphomycetes from Canadian streams. I. Basidiomycetous anamorphs. Mycotaxon 32, 339-351.

3. Sati, S.C., Tiwari, N., and Belwal, M. (2002) Conidial aquatic fungi of Nainital, Kumaun Himalaya, India. Mycotaxon 81, 445-455.

4. Bills, G.F. and Polishook, J.D. (1992) Recovery of endophytic fungi from Chamaecykaris thyoides. Sydowia 44, 112.

5. Dreyfus, M.M. and Chapela, I.H. (1992) The potential of fungi in discovery of novel, low molecular weight pharmaceuticals. In The Discovery of Novel Natural Products with Therapeutic Potential. Butterworth Publications, Biotechnology Series, London.

6. Barlocher, F. (1991) Intraspecific hyphal interactions among aquatic Hyphomycetes. Mycologia 83, 2-88.

7. Khan, M.A. (1987) Interspecies interactions in aquatic hyphomycetes. Bot. Mag. Tokyo 100, $295-303$.

8. Shearer, C.A. and Zare-Maivan, H. (1988) In vitro hyphal interactions among wood and leaf-inhabiting Ascomycetes and fungi imperfecti from freshwater habitats. Mycologia 80, 31-37.

9. Chamier, A.C., Dixon, P.A., and Archer, S.A. (1984) The spatial distribution of fungi on decomposing alder leaves in a freshwater stream. Oecologia 64, 92-103.

10. Gulis, V.I. and Suberkropp, K. (2003) Interactions between stream fungi and bacteria associated with decomposing leaf litter at different levels of nutrient availability. Aquat. Microb. Ecol. 30, 149-157.

11. Fisher, P.J., Anson, A.E., and Webster, J. (1988) Quinaphthin, a new antibiotic, produced by Helicoon richonis. Trans. Br. Mycol. Soc. 90, 499-502.

12. Adriaenssens, P., Anson, E., Begley, M.J., Fisher, P.J., Orrel, K.G., Webster, J., and Whitehurst, J.S. (1994) Quinaphthin, a binaphthyl quinonoid secondary metabolite produced by Helicoon richonis. J. Chem. Soc. Perkin Trans. 1 No. 14, 2007-2010.

13. Harrigan, G.G., Armentrout, B.L., Gloer, J.B., and Shearer, C.A. (1995) New bioactive natural products from two Anguillopsora species. In The VI International Marine Symposium. A Meeting of the British Mycological Society, 8-15 July, 1995. Program Abstracts, p. 135, University of Portsmouth., England.

14. Platas G., Pelaez, F., Collado, J., Villuendas, G., and Diez, M.T. (1998) Screening of antimicrobial activities by aquatic hyphomycetes cultivated on various nutrient sources. Cryptogam Mycol. 19, 33-43.

15. Gulis, V.I. and Stephanovich, A.I. (1999) Antibiotic effects of some aquatic hyphomycetes. Mycol. Res. 103, 111115 .

16. Gloer, J.B. (1995) Bioactive metabolite from aquatic fungi. In The VI International Marine Mycological Symposium. A Meeting of the British Mycological Society, 8-15 July, 1995.Program Abstracts, p. 65, University of Portsmouth: England.

17. Fisher, P.J., Petrini, O., and Webster, J. (1991) Aquatic hyphomycetes and other fungi in living aquatic and terrestrial roots of Alnus glutinosa. Mycol. Res. 95, 543-547.

18. Ananda, K. and Sridhar, K.R. (2002) Diversity of endophytic fungi in the roots of mangrove species on the west coast of India. Can. J. Microbiol. 48, 871-878.

19. Sati, S.C. and Belwal, M. (2005) Aquatic hyphomycetes as endophyte of riparian plant roots. Mycologia 97, 45-49.

20. Fokkema, N.J. (1973) The role of saprophytic fungi in antagonism against Drechslera sorokiniana (Helminthosporium sativum) on agar plates and on rye leaves with pollen. Physiol. Plant Pathol. 3, 195-205.

21. Vaidya, G.S., Shrestha, K., and Wallander, H. (2005) Antagonistic study of ectomycorrhizal fungi isolated from Baluwa Forest (Central Nepal) against with pathogenic fungi and bacteria. Scientific World, 3, 49-52.

22. Raviraja, N.S., Maria, G.L., and Sridhar, K.R. (2006) Antimicrobial evaluation of endophytic fungi inhabiting medicinal plants of the Western Ghats of India. Eng. Life Sci. 6, 515-520.

23. Gbolagade, J., Kigigha, L., and Ohimain, E. (2007) Antagonistic effects of extracts of some Nigerian higher fungi against selected pathogenic microorganisms. American-Eurasian J. Agric. Environ. Sci. 4, 364-368.

24. Tian, X.L., Cao, L.X., Tan, H.M., Zeng, Q.G., Jia, Y.Y., Han, W.Q., and Zhou, S.N. (2004) Study on the communities of endophytic actinomycetes from rice and their antipathogenic activities in vitro. World J. Microb. Biotech. 20, 303-309. 
This article should be cited as follows:

Sati, S.C. and Arya, P. (2010) Antagonism of some aquatic hyphomycetes against plant pathogenic fungi. TheScientificWorldJOURNAL 10, 760-765. DOI 10.1100/tsw.2010.80. 

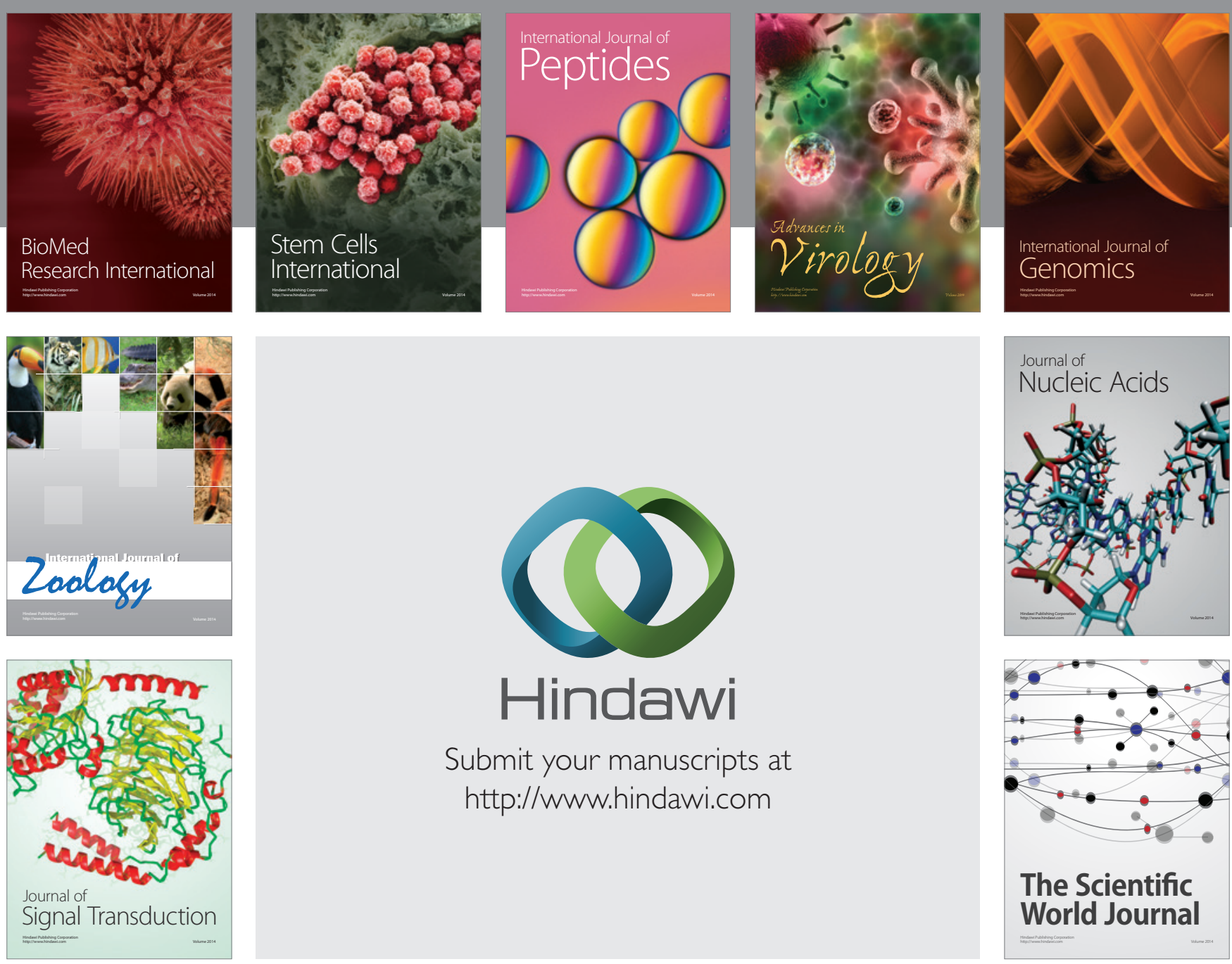

Submit your manuscripts at

http://www.hindawi.com
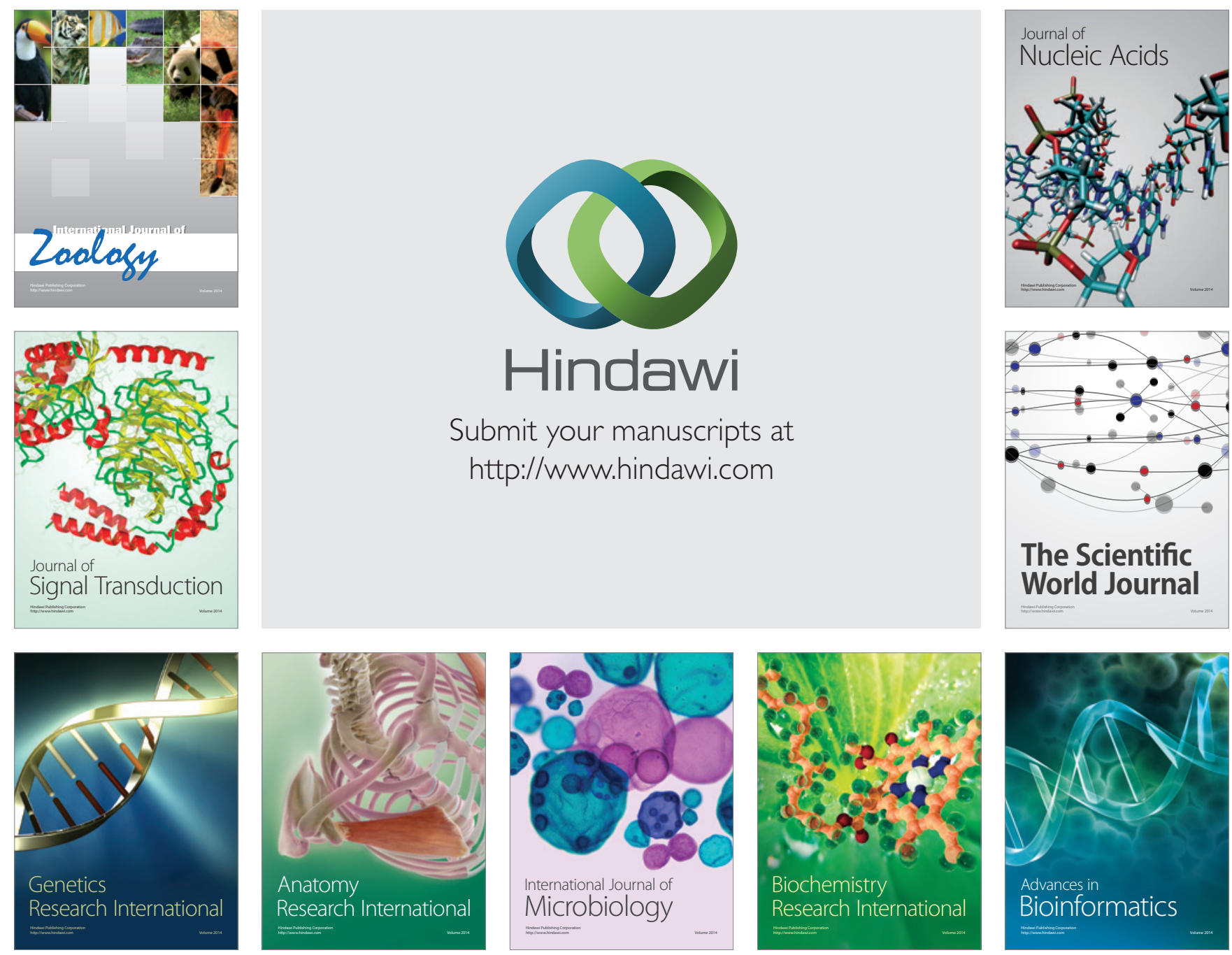

The Scientific World Journal
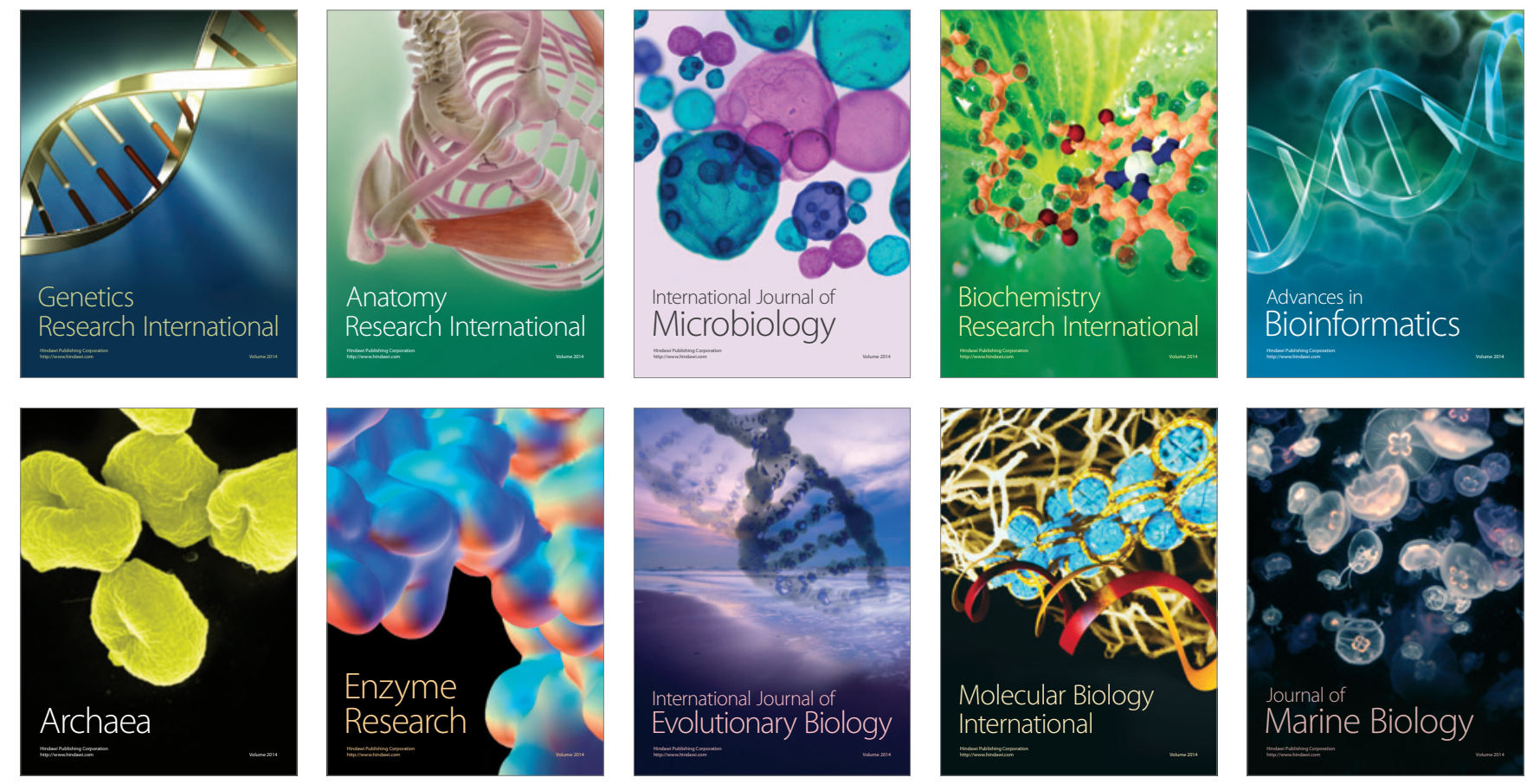